\title{
Not in my back yard
}

\section{Munich}

As the barriers between Eastern and Western Europe come down, some nuclear power plant operators in the West are wondering if they may not now have a golden opportunity to set up some of their unpopular generating facilities next door. The Czechoslovak government has already begun negotiations with French and German companies to build plants at the Temelin site, near the Austrian border. The plants would be financed by selling electric power to Italy, transmitted via high-tension cables running through Austria.

The idea of building new nuclear plants in Czechoslovakia is controversial, especially in neighbouring Austria, which abandoned its own nuclear programme in 1987. Anti-nuclear activists based in Austria have been campaigning for years against existing Czechoslovak reactors.

Nevertheless, there are clear benefits for Czechoslovakia in expanding its nuclear programme in this way. It could gain access to important Western technology and at the same time reduce its dependence on high-sulphur coal, which has devastated the environment (see Nature 344, 91; 1990).

Czechoslovakia currently derives 27 per cent of its electricity from nine Sovietbuilt nuclear reactors at three sites. Another seven reactors that are under construction will raise dependence on nuclear power to 45 per cent by the year 2000. The design of two reactors, at Bohunice near the Austrian border, has been criticized as fundamentally flawed. They are of the same type (VVER 440-V 230 ) as those at Greifswald, East Germany, which were last month judged to be hopelessly unsafe by a West German safety commission and ordered to be shut down. There are four reactors of the same type still operating in Bulgaria and four more in the Soviet Union (see Nature 344, 282; 1990). The remaining seven Czechoslovak $440 \mathrm{MW}$ reactors are of a slightly more modern design.

So far, the newly elected democratic government of Czechoslovakia has continued its Communist predecessor's support for nuclear power. As recently as 27 June, an adviser to the now-defunct Ministry for Fuels and Energy, Frantisek Suranski, declared on Austrian television that Czechoslovakia "sees no reason or option to give up nuclear power now". Even the activist Environment Minister for the Czech republic, Bedrich Moldan, has said that he favours the continued operation of existing nuclear plants and the completion of plants under construction.

Prime Minister Marian Calfa announced on 3 July that several coal-burning plants

in northern Bohemia would be closed by the end of the year. That decision will put more pressure on nuclear plants to fill the resulting energy gap. A moratorium declared in January by the interim government on construction of the two newest 1,000 MW plants at Temelin does not mean that nuclear power is out of favour these are the plants that the government may replace with new Western designs.

Austrian objectors to nuclear power have made several arguments against Czechoslovakia's plans to expand its nuclear capacity. They point out that no one has studied the real cost of Czechoslovak energy or how much Czechoslovak industry could improve its energy-efficiency. According to Michael Undorf of the Austrian Greenpeace organization, the Austrian government has offered to form a joint commission to study this problem, and Moldan has tried to get the Czech government to accept, but without result.

Once Czechoslovakia carries out such studies, said Vienna University ecology professor Bernd Lötsch on Austrian television on 27 June, the Czechoslovak government will realize how much more effective it is to improve the efficiency and environmental standards of industry and existing power plants than to build new nuclear plants. Undorf agrees, saying "We hope that [the prohibitive cost of new plants] is what ultimately defeats the idea."

\section{NUCLEAR CLEAN-UP}

\section{Runaway costs cause sharp reduction}

\section{Boston}

ESTIMATES of the cost of the first phase of the immense project to redress environmental damage occurring at US government facilities used to manufacture nuclear weapons have doubled in less than a year, according to projections released last week by the Department of Energy (DoE). The first five years of the 30-year clean-up are now calculated to require more than $\$ 28,000$ million. The entire clean-up operation is expected to cost in the vicinity of $\$ 100,000-$ $\$ 200,000$ million dollars over the next few decades.

DoE says that the projected costs are rising because of a better assessment of the job's technical requirements, and because of the increases in charges that are demanded by contractors to protect themselves against the lawsuits that may arise during the clean-up procedures. Provisions in current hazardous waste laws, as well as increases in environmental litigation by the states and the Environmental Protection Agency, conspire to make contractors increasingly wary, according to Leo Duffy,
But conservation alone will not solve the Czechoslovak energy problem, according to Thomas Horacek, a researcher in an institute attached to the former Czechoslovak Energy Ministry. Czechoslovakia is a net importer of electricity from other Eastern European states, and more electricity will be needed relative to other forms of energy as the country modernizes its economy, he says.

Michael Schneider of the Paris-based World Information Service on Energy points out that schemes to finance new nuclear plants by exporting electricity have never worked in the past. Western nuclear power plant producers came close to realizing a deal with Turkey between 1983 and 1987. In exchange for a complete plant built by a Western company, Turkey was to have exported power for 15 years. But by 1987 , both West German and Canadian companies had pulled out of the scheme.

If Italy does not in the end prove a willing customer, it is difficult to imagine there being any other market for electricity in another nearby country. Before German unification began, both West Germany and France were producing electricity surpluses, and by the time Czechoslovakia is in a position to build new plants, West German utilities are likely to have met the entire demand in what is now East Germany. Environmentalists have already vowed to fight if Austria moves towards approving the construction of power lines to Italy from Eastern Europe.

Steven Dickman director of DoE's environmental management office.

Responses to the new cost estimates were mixed. While the Energy Department continues to win high marks for the glasnost fostered under Energy Secretary James Watkins' watch, critics complain that the department is absorbing the costs of cleaning-up into operating budget as a way to maintain personnel numbers even while facilities are being shut down (see Nature 342,$5 ; 1989$ ). Some observers think that clean-up costs are likely to go higher still, so high that it may not be politically feasible to pay them.

Even if Congress does allocate the necessary funding, the current cost projections and the operation itself are predicated on the assumption that the Department of Energy will successfully complete its nuclear waste repositories in Nevada and New Mexico. But both of these facilities are far from completion and continue to be fraught with political opposition and technical problems.

Seth Shulman 